\title{
Reconciling Universality and Particularity through a Cosmopolitan Outlook on Human Rights
}

\author{
Rebecca Adami \\ Stockholm University, Sweden
}

\begin{abstract}
Human rights are today criticized as not compatible with different cultural values and the debate has circulated around Asian values and Islamic values as in dichotomy with human rights as universal ethics (Ignatieff, 2003). The theoretical dichotomy between universality and particularity is questioned pragmatically in this paper through a historical study. The working process of drafting the Universal Declaration of Human Rights (UDHR) in 1946-48, which included thousands of people, is explored as a cosmopolitan space in which individuals from different cultural contexts met to negotiate human rights through cultural narratives. The process where particular values were negotiated with universal notion on human rights resulted in a common proclamation (UDHR) without a common philosophical or ideological ground. This paper puts forth a thesis that human rights discourse can work as a cosmopolitan space, in which particular value systems meet in processes characterized by conflict and cohesion. Hence human rights can be understood as a master narrative compatible with different conflicting cultural narratives (Gibson \& Somers, 1994).
\end{abstract}

\section{Introduction}

The tension between particularity and universality has been articulated within cosmopolitanism in many ways, from Nussbaum’s (2003) words of ‘transcending boundaries of class, gender and nation with narrative imagination’ to Benhabib’s (2008) notion of 'universalist norms mediated with the self-understanding of local communities' (Benhabib 2008, p.71). Hence, we have seen a shift in cosmopolitanism from an abstract cosmopolitanism from above (Nussbaum 2003) towards a rooted cosmopolitanism from below (Benhabib 2008). Still, the articulated theoretical problem of a dichotomy between universalism and particularism continues being debated within cosmopolitanism. Negotiating and reconciling universality of human rights with particularity of local, cultural values is one example of a presumed dichotomy between universality and particularity. Human rights can be seen as cosmopolitan ethics, a suggestion made already in 1998 by John Charvet (Charvet 1998).

What I aim to do in this paper is to explore empirically the supposed dichotomy between universalism and particularism by facing some allegations of Eurocentrism against the 
drafting of the UDHR in 1946-48. When exploring the presumed dichotomy between universality and particularity empirically, I argue that the drafting of the Universal Declaration of Human Rights can be seen as occurring in a cosmopolitan space, where human rights were negotiated on conflicting, particular value grounds. Negotiating universal ethics in a space characterized as cosmopolitan has been discussed earlier by Charvet (1998) and Borges (2010). Both Charvet and Borges point to excluding boundaries of cosmopolitan space, in relation to power. The drafting of the universal declaration of human rights in 1948 was a process including representatives to the UN Commission on Human Rights and members of the UNESCO Committee, hence setting strict boundaries of inclusion and exclusion in relation to political power. This conceptualization of cosmopolitan space contextualizes the tensions and conflicts arising in negotiating human rights, but also the temporal consensus on universal principles of human rights in 1948. By looking at the process when human rights were negotiated, as a relational, contextual and historical process, illuminates how universality and particularity can be reconciled temporarily, on conflicting grounds.

\section{The Impasse in Discourse on Human Rights}

The Universal Declaration on Human Rights from 1948 might seem abstract in its wordings, detached from any local contexts or values people relate to in daily lives. The first article of the Declaration reads, 'all human beings are born free and equal in dignity and rights. They are endowed with reason and conscience and should act towards one another in a spirit of brotherhood’ (UDHR, article 1). When read and analyzed by European scholars though, the concepts of 'dignity', 'reason' and 'consciousness' have been interpreted as originating from western philosophy, and the term brotherhood has been understood in the light of the French revolution and 'rights' have been seen as deriving from the American declaration of independence (Griffin 2008; Ignatieff 2003). So even if the UDHR contains broad and inclusive concepts that give it a character of abstractness in the sense that there are no outright references to different religious or cultural values in the document, the UDHR has been read by western scholars through a western, liberal approach to its content.

Within the discourse on human rights, the most dominant view today is that human rights need to be renegotiated in order to meet charges of ethnocentrism. Ignatieff (2003) argues that the process of drafting human rights was westernized. Although he admits that 'many 
traditions were represented at the drafting', he concludes that western drafters played a predominant role in the drafting of the document (Ignatieff 2003). He said that there was an Islamic questioning of human rights already in 1948, when Saudi Arabia did not vote for the article on religious freedom (Ignatieff 2003). He chooses not to mention the other states represented in the UN Commission with large Muslim populations, who voted for the article on religious freedom, such as Pakistan, India, Syria, Egypt, Iran and Lebanon. Furthermore Ignatieff (2003) only mentions western drafters in the UN Commission, such as Eleanor Roosevelt from USA, John P. Humphrey from Canada and René Cassin from France, but not the Pulitzer Prize winner Colonel Romulo from the Philippines, or Peng-Chun Chang from China who was vice chairman of the Commission, or Charles Malik, Lebanese delegate and philosopher, or Hansa Metha, Indian legislator.

The lingering allegation of ethnocentrism, according to Morsink (1999) is in part caused by the fact that very few people seem to know what was said and done during the drafting process. 'This ignorance has led to numerous misconceptions about how the document was written and what it and its various parts mean’ (Morsink 1999 p.xiii). The UDHR has been criticized since its drafting as presenting 'western values'. According to Tesón, 'what may be regarded as a human rights violation in one society may properly be considered lawful in another, and Western ideas of human rights should not be imposed upon Third World societies (Tesón 1985, p.878). Accordingly, Ignatieff argues against 'faith in human rights' and equalizes human rights negotiations with political debates, by bringing up challenges to human rights legitimacy today, such as dichotomy between Islamic values and human rights or East Asian values and human rights. 'An Asian model puts community and family ahead of individual rights and order ahead of democracy and individual freedom. In reality, there is no single Asian model yet it has proven useful for Asian authoritarians to argue that they represent a civilization challenge to the hegemony of Western models' (Ignatieff 2003, p.63). The claim of Asian values as not compatible with human rights has been debated by Xiaorong Li (2006) who writes that:

\footnotetext{
'The argument that rights are culturally specific implies that social norms originating in other cultures should not be adopted in Asian culture. But, in practice, advocates of the 'Asian view' often do not consistently adhere to this rule. Leaders from the region pick and choose freely from other cultures, adopting whatever is in their political interest. They seem to have no qualms about embracing such things as capitalist markets and
} 
consumerist culture. What troubles them about the concept of human rights, then, turns out to have little to do with its Western origin' (Li 2006, p.401).

The conflict in discourse is rather based on different conceptions regarding whether human rights are based on western philosophy and ideology or not. The ‘universality' of human rights is criticized as a western concept, where particularity is understood as 'other' particular values than values deriving from 'Christianity', 'liberalism' and 'natural law'. What is worth noting is that western scholars and philosophers generally argue against reconciling 'universal human rights' and particular values, by arguing that 'other' particular value systems than western, liberal values are not compatible with human rights.

\section{A cosmopolitan outlook on negotiating human rights in 1948}

When the UDHR is read and narrated in diverse national and local contexts, I argue that tensions may arise between different local interpretations of human rights based on different particular cultural, religious, political and ideological values (Andreopoulos 1997). I refer here to public or cultural narratives (Horsdal 2011), of what Gibson and Somers (1994) view as cultural, religious, national, ethnic and other group narratives, revealing the particular values in a specific context. This means that there could be stories in other parts of the world, revealing different contextual frames for understanding human rights values. Public or cultural narratives are collective stories explaining the events in our lives by evaluation grounded in particular values (Horsdal 2011; Gibson and Somers 1994). These cultural, religious and ethnic values are not subjective, but rather particular. If human rights are narrated within different cultural narratives where people make sense of cosmopolitan values in local contexts, do we need to find common ideological foundation for human rights in order to prove them universally reasonable? The abstract problem of the dichotomy between universal and particular values can be traced to an historical, contextual and relational setting, empirically grounded in the drafting of the human rights in 1948. 'Historicizing' the concept of human rights is a way to oppose the idea that concepts are a-historical and non-relational (Gibson and Somers 1994). The conceptual analysis explores a cosmopolitan space where human rights were conceptualized in different, cultural narratives by turning to primary sources of archived UN documents from UNESCO library in Paris. 


\section{UDHR - drafted in a Cosmopolitan Space in 1948}

The tensions in the world were strong after the Second World War. Delegates representing post colonial countries met in discussions with their post colonial rulers. Delegates from what would become the power struggle between the East and West block in the Cold War after the Second World War met from opposite sides of economic ideologies. Hence, the historical context for the drafting process challenged power positions, creating a possible conflict zone. It was the first time in history that people from all over the world met in a diplomatic arena, negotiating and discussing human rights from different ideological and cultural backgrounds. The working process of drafting the UDHR, engaging thousands of people in 194948 opened up what in this paper will be referred to as a cosmopolitan space. Was the process, as suggested by some scholars a process characterized by ideological domination (Ignatieff 2003)? Was the drafting of the UDHR another postcolonial step of cultural imperialism (Griffin 2008)? Conducting an historical study of the concept human rights in relation to universality and particularity, enables an exploration of how universalism and particularism can be negotiated in a cosmopolitan space.

\section{The United Nations Commission on Human Rights}

The United Nations Commission on Human Rights (henceforth the Human Rights Commission) held three sessions and over hundred meetings between 1947 and 1948 in Lake Success, Geneva and Paris where they discussed the content of the six drafts that would later become the UDHR. In the beginning of the process, the delegate who wrote the initial draft, John P.Humphrey from England, compiled all earlier works on rights he could find, from South America amongst others and when he presented this at one meeting, he was asked what philosophy had guided the Secretariat's work. Humphrey had no answer to this question, 'for the simple reason that the draft was based on no philosophy whatsoever' (Glendon 2001, p.58).

In 1948, 56 member states to the UN voted for the UDHR. The most prominent and active delegations on the Human Rights Commission, set up to draft the Declaration, were China, Lebanon, India, Chile, Philippines, France, England, Soviet Union and the United States. The old generation of countries like France and England, basing their attitude on colonial structure of the world, had to change their strategy of trying to ignore the smaller nations during the sessions. It took three weeks for the 58 delegates from all over the world to first negotiate and discuss and later pass two articles in the Declaration The pressure from a new generation of 
human rights activists and advocates, such as Charles Malik, philosopher and diplomat from Lebanon, Carlos Romulo, Pulitzer Prize journalist from the Philippines (who was against colonialism), Hansa Metha, an Indian legislator and outspoken critic of Britain’s colonial policies and Hernán Santa Cruz of Chile, representing the economically developing countries, was something new in diplomatic relations. Charles Malik, the delegate from Lebanon had a crucial role in the passing of the UDHR and was elected president of the Economic and Social Council, to which the Human Rights Commission had to submit its draft Declaration. In the fall of 1948 he was elected chairman of the UN's third committee (the Social, Humanitarian, and Cultural Affairs Committee), which had to present the Declaration for approval to the General Assembly at its December meeting in Paris (Glendon 2001, p.124). The two philosopher-diplomats P.C.Chang (Chinese delegate) and Charles Malik (Lebanese delegate) were by most accounts the intellectual leaders of the Human Rights Commission (Glendon 2001, p.145).

The process of debating and negotiating the human rights declaration in over one hundred sessions with delegates from all over the world resulted in the exclusion of particular values in the declaration since it was necessary to have everyone agree on the wording of the text. Article one in the UDHR reads today,

'All human beings are born free and equal in dignity and rights. they are endowed with reason and conscience and should act towards one another in a spirit of brotherhood' (UDHR, article 1).

The lengthy process was partly due to political debates, but also to a great extent to different value systems being in opposition to each other. The Iraqi delegation agreed with the Communists that people are often born into unequal circumstances, which is why they wanted to keep Article 1 totally on an ethical plane (Morsink 1999, p.292). Adbul Kayaly, the delegate from Syria, wanted to retain the word 'born' as it would exclude the idea of hereditary slavery (Morsink 1999, p.293). The Brazilian delegation withdrew their amendment on reference to God, when the Philippine delegation took out their phrase 'by nature ${ }^{1}$.The representative from India, Mohammed Habib, said he 'favored the use of the word caste rather than birth as the latter was already implied in the Article. This observation led several delegates to state their objections to both caste and class as not accurate

\footnotetext{
${ }^{1}$ http://archives.un.org
} 
(Uruguay), as categories that 'human beings were trying to outgrow' (US) or as too specific (Philippines). Even though the drafting process was lengthy with endless debates on different wordings and its interpretations, this improved the chances for the UDHR to be more acceptable in a world of plurality. As Glendon (2001) writes, 'perhaps only someone like Malik, from a small, newly independent country, could understand how important it was for every member state to have a sense of ownership with respect to the UDHR' (Glendon, 2001, p.143). The Chinese delegate to the Human Rights Commission refrained from proposing specific Chinese values such as good manners and consideration for others in the declaration and hoped that:

[T] he others would show equal consideration and withdraw some of the amendments to article 1 which raised metaphysical problems. For western civilization too, the time for religious intolerance was over. Those who believed in God could still find the strong opening assertion of article 1 the idea of God, and at the same time others with different concepts (of human nature) would be able to accept the text (Glendon 2001, p.146).

Since no delegation would vote for the approval of the UDHR if the human rights declaration was written according to one dogmatic ideology, compromises had to be made by excluding references to 'natural law', 'God', 'Allah', 'Christian faith', Marxism’ etc. The UN archives have documented these ideological debates between human rights based on religious grounds and political systems such as liberalism and communism. For example the Cuban delegation wanted to shape the UDHR more closely on the model of the Bogota Declaration adopted that April by the nations of Latin America (Morsink 1999, p.232). Watt of Australia liked the Cuban proposal that a 'more prominent place should be assigned to freedom of conscious and religion' than that of social and economic ones (Morsink 1999, p.233).

The process leading to the drafting of the UDHR was hence one of excluding all reference to ideology and philosophical foundation and including an exhausting non-discrimination list for the right to human rights, listing different individual and group belongings; 'Everyone is entitled to all the rights and freedoms set forth in this Declaration, without distinction of any kind, such as race, colour, sex, language, religion, political or other opinion, national or social origin, property, birth or other status' (UDHR, article 2). 


\section{The UNESCO Committee on the Philosophical principles of the Rights of Man}

The UNESCO report from 1948 to the Human Rights Commission was a publication of the inquiry made by UNESCO of the philosophical principles of human rights. The UNESCO Committees report from 1948 exhibits different cultural, philosophical, religious and political interpretations of human rights than the dominant literature on human rights today.

Philosophers from different parts of the world were asked to send written contributions to the UNESCO Committee on the Philosophical principles of the Rights of Man (henceforth UNESCO Committee). There were contributions on 'The Rights of man and the Islamic Tradition', 'Human Rights in the Chinese Tradition', 'Human Freedoms and the Hindu Thinking' amongst other. According to Chung-Shu Lo, who wrote the Chinese contribution to the UNESCO Committee, the idea of human rights was very old in the Chinese tradition,

The term we use to translate 'rights' now is two words 'Chuan Li', which literally means 'Power and Interest'. This of course does not mean that the Chinese never claimed human rights or enjoyed the basic rights of man. In fact, the idea of human rights developed very early in China, and the right of the people to revolt against oppressive rulers was very clearly established (UNESCO 1948, p.185).

According to this text on the Chinese tradition from 1948, human rights as a concept could be traced back in Chinese historical texts, suggesting that conceptually human rights reconciled with particular Chinese value systems. Through a cosmopolitan view of culture as dynamic and in constant change, the text does not imply anything constant in 'reality' but rather serves as an example in time on how universal notions on human rights were reconciled with particular values within a Chinese tradition, as conceptualized at that certain period in time. The UNESCO Committee also published a written contribution on the Islamic tradition in their report, by Humayun Kabir. Although the text is written in1948 it is written with a sense of increased cosmopolization and interconnectedness of people. According to the Islamic contribution by Humayun Kabir, human rights should be based on recognition of the equal claims of all individuals within one common world (UNESCO 1948, p.189). Even if there were divergent conceptions of human rights according to Kabir, the interrelation of people and global communication had marked the end of closed cultural systems,

The first and most significant consideration in framing any charter of human rights today is that it must be on a global scale. In the past, there have been many civilizations but 
never one world civilization. Two different conceptions of human rights could and sometimes did subsist side by side and because of lack of communication, could even be unaware of one another. Today such a state of affairs is unimaginable. Whatever happens in one corner of the globe has an almost immediate repercussion on the other parts. Days of closed systems of divergent civilizations and, therefore, of divergent conceptions of human rights are gone for good (UNESCO 1948, p.191).

Kabir emphasized in his text the need of equal claims of all individuals in a common world. The contradiction between universal and particular was according to Kabir's text due to the dominant conception of human rights as only being rights for European people.

It is necessary to emphasize this because of one fundamental flaw in the western conception of human rights. Whatever be the theory, in practice they often applied only to Europeans and sometimes to only some among the Europeans. In fact, the western conception has to a large extent receded form the theory and practice of democracy set up by early Islam, which did succeed in overcoming the distinction of race and colour to an extent experienced neither before nor since (UNESCO 1948, p.192).

Kabir suggests in the text that particular values grounded in Islamic tradition were in line with universal values of human rights and that an Islamic democracy could and had historically reconciled non-discrimination in 'reality'. The tension or conflict in the text is suggested to be between practical inclusion of people who have the right to rights. The proposed conflict did not lie in Islamic values contra western values, but in the failure of practically including others than Europeans as rights bearers. The contribution from a Hindu perspective, by Puntambekar, presented a conception of the human being as spiritual, which may differ from a traditional western conception of human beings:

Then we must note that there is an incalculable element in the human will and an endless complexity of human nature. No system, no order, no law can satisfy the deep potential demands of a great personality, be they religious, political, social or educational. No system can satisfy the growing needs of a dynamic personality (UNESCO 1948, p.197).

Hence, Putambeker subscribed in his text to universal human rights, but on a different conceptual ground than the Islamic or Chinese value systems. If human rights may be reasonable conceptually within different particular value systems, then universal principles 
could be reconciled with different particular values. But could human rights find a common ground in a specific value system, perceived as universally reasonable? The UNESCO Committees’ report exhibited antagonistic value systems, each and everyone subscribing to human rights in their particular cultural narrative. The process for the UNESCO Committee to analyze the written contributions from philosophical perspectives can be viewed as a process requiring a dialectical mode of thinking, by conceiving cultural differences as neither absolute nor necessary antagonistic, but relationally defined (Rizvi 2008). Studying the concept of human rights in a text below by Putambekar might at first sight be conceptually divergent from other texts in the UNESCO Committee report on liberal views on human rights. Putambekar writes that 'what we want is freedom from want and war, from fear and frustration in life' (UNESCO 1948, p.199).

The claims for freedom in the text are similar to the liberal conception of rights, espoused by the contemporary American president Franklin D. Roosevelt, namely, freedom from fear, from want, freedom of speech and worship. According to Putambekar, 'freedom is necessary because authority is not creative' (UNESCO 1948, p.198). From a cosmopolitan perspective cultural differences are dynamic and interconnected, which implies that cultural narratives cannot be distinguished from each other on static terms, but they rather intertwine. In the words of Putambekar, the discussions on universal human rights were necessary but difficult since human beings were particular, as religious, racial, caste or group beings:

To talk of human rights in India is no doubt very necessary and desirable, but hardly possible in view of the socio-cultural and religio-political complexes which are so predominant today. There are no human beings in the world today, but only religious men, racial men, caste men or group men [ sic] (UNESCO 1948, p.198-199).

This situatedness in the world that Putambekar addresses as a great hindrance towards discussing and learning human rights in particular contexts is what Rizvi (2008) suggests as the point of departure in cosmopolitan negotiations. Cosmopolitan negotiations and consensus on human rights is according to Rizvi helping people to come to terms with their situatedness in the world, of their knowledge and cultural practices (Rizvi, 2008). Would this mean that people could identify themselves as human rights bearers if human rights were interpreted on a local level as 'Islamic rights', 'Christian rights' or 'women's rights'? In the report by the UNESCO Committee, different (and sometimes antagonistic) cultural narratives were related 
to the notion of universal human rights, even though the concepts of 'rights', 'claims' or 'human rights' were not present in the particular tradition. Foundation for the same set of rights in divergent local value systems could be found, but when these same lists of rights were discussed and legitimized in another, seemingly antagonistic cultural narrative, conflict arose. The aim of the UNESCO Committee was not to find a common foundation for human rights, but rather to invite thinkers from different parts of the world to an open discussion on the philosophical foundation for human rights. The report the UNESCO Committee, with its particular interpretations of human rights, was not referred to in the UDHR, rather the UDHR text is stripped of any particular value reference.

\section{Common agreement on human rights based on conflicting grounds}

Human rights were referred to as practical principles in the UNESCO Committee. According to Jacques Maritain, French philosopher on the UNESCO Committee, the goal of UNESCO was a practical goal and he said that 'agreement between minds could be reached spontaneously, not on the basis of common speculative ideas, but on common practical ideas, not on the affirmation of one and the same conception of the world, of man and of knowledge, but upon the affirmation of a single body of beliefs for guidance in action' (UNESCO 1948, Foreword, p.II).

The drafting process in the Human Rights Commission in 1948 aimed at excluding all reference to ideology in the final draft declaration in order for human rights to be understood in their local and cultural context, although orally the discussions and debates on particular values in relation to universal human rights were lengthy and ambitious. The UNESCO Committee, on their part, included all contributions from different cultural, religious and political regions in their report, to exhibit the different local interpretations of human rights. Both of these processes resulted in similar lists of human rights. The initial question raised in this paper addressed the presupposed polemic between local and universal aspects of human rights that extends beyond borders. The drafting process of the UDHR that included both the Human Rights Commission and the UNESCO Committee was held on a national level, between national delegates and invited thinkers from different countries. Even so, by studying the texts deriving from this drafting process, it occurs to the reader that the drafters, as individuals in a social context, went through changes in their conceptions of human rights from sharing their local and particular 'stories' or cultural narratives and by listening to so many other cultural narratives. 
The significance of this paper lies in its illumination of the drafting of the UDHR as it was worked on not only by the Human Rights Commission, but also the UNESCO Committee. This highlights the fact that already in 1947 people from different political and philosophical spheres and geographical areas were preoccupied with finding universal foundations of and justifications for the declaration. If the universality and particularity could be negotiated in a cosmopolitan space in 1948, the consensus of human rights, however temporal, can work as a pragmatic response to the theoretical dichotomy of universality and particularity regarding human rights. Note that the aim was not to found one universal foundation of and justification for the UDHR. The work of the Human Rights Commission and the UNESCO Committee were two separate processes, ending with the same list of universal human rights. 'Is there anything surprising in systems antagonistic in theory converging in their practical conclusions?' (UNESCO 1947, p.7) asked Jacques Maritain in the foreword to the UNESCO Committees' report. One insightful experience drawn by Maritain was that antagonistic theories and reasons for human rights could justify the universality of human rights, but not bring agreement on the foundation for human rights.

Unesco’s part was to consult philosophers and assemble their replies. (...) Many schools of thought are represented, each of which brings to the whole its particular view and justification of individual rights (...). The paradox is that such rational justifications are at once indispensable, and yet powerless to bring about agreement between minds. They are indispensable because each one of us believes instinctively in the truth, and will only assent to what he himself has recognized as true and based on reason. They are powerless to bring about a harmony of minds because they are fundamentally different, even antagonistic; and why should this surprise us? (UNESCO 1948, Foreword, p.I)

In other words, human rights as practical principles are reasonable within particular value systems, which are in opposition to each other. The problems in the foreground in formulating human rights were the supposed polemic between 'universal' and 'particular' values. Although, after the extensive political sessions and philosophical discussion between individual contributors from all over the world, the polemic was between different particular values systems, not between universal practical principles of human rights and diverse cultural values. As Jacques Maritain says in the foreword to the UNESCO report: 
At one of the meetings where Human Rights were being discussed, someone expressed astonishment that certain champions of violently opposed ideologies had agreed on a list of those rights. "Yes", they said, "we agree about the rights but on condition that no one asks us why”. That "why” is where the argument begins. (UNESCO 1948, Foreword, p.I)

\section{The discourse on Human Rights as a Cosmopolitan Space}

Cosmopolitanism does not imply abandoning our distinctive ways of living nor does it entail a sense of rootlessness (Hansen 2009, p.593). A conclusion can be drawn that understandings of human rights originate from our locality and through our particular value systems, with which we identify. Narrating our local values within a human rights discourse interconnects us to millions of others, rooted in their particular value system. Drawing on thoughts from Langlois (2001) the understanding of 'universality' can move beyond the impasse, of theoretical struggles of human rights legitimacy, towards reconciling 'universal' and 'particular' values in the cosmopolitan space that human rights offer as discourse. Langlois (2001) combines universal values with local stories, identifying 'universal' human rights as a language that can be seen as a common discourse through which cultural narratives are negotiated. Re-thinking 'universality' from the imperialistic understanding of the concept, as the triumph of one ideology over another, to an inclusive concept, is useful for narrating particular experiences within a human rights discourse on a global arena.

\footnotetext{
'Preventing the discourse of human rights from stagnating around the old polarities: relativism versus universalism, individualism versus communitarianism, economic rights versus political rights, the discourse on human rights may thus be regarded as an entry point into the global community for the marginalized and oppressed' (Langlois 2001, p.164).
}

Taking the critical-ethical aspects of cosmopolitanism seriously is thinking the universal through the particular and acknowledging the tensions that may arise. 'In thinking the discourse differently is to think it through the stories, narratives and traditions that define us as individuals and communities, rather than trying to avoid them’ (Langlois 2001, p.165).

'Avoiding the stories that define our identities means that whatever we are protecting with the human rights discourse will always be something that is slightly different from and out of touch with those things we value most. The issue here is how to use the 
discourse of human rights as a means for telling our local stories to a larger audience.' (Langlois 2001, p.165)

\section{Conclusion}

Ignatieff's way of reconciling human rights universalism with cultural and moral pluralism is by arguing for a thin, universal theory of human rights as negative liberty. I argue that reconciliation of human rights universalism with cultural and moral pluralism has already happened, if one takes into account the negotiations and temporal consensus that was actually reached in 1948 on a universal set of human rights.

The theoretical dichotomy between universality and particularity, as articulated in cosmopolitan literature (Nussbaum 2003; Benhabib 2008) has been questioned on a pragmatic level by looking at the drafting of the UDHR in 1946 - 1948. Approaching human rights discourse as a cosmopolitan space opens up for critical-ethical dimensions of pluralism, where conflict and tensions are part of understanding the relation between universality and particularity in regard to human rights. Claiming human rights as universal in 1948 through different and antagonistic ideological value systems was possible by the abstract wording in the UDHR. Dominant European narratives (Ignatieff 2003; Griffin 2008) on the origin and cultural heritage of human rights in the documents have excluded alternative and equally justifiable philosophical and ideological foundations for human rights principles.

By turning to primary sources from 1948 I have pragmatically questioned the lingering allegations of ethnocentrism surrounding the drafting of the UDHR. I argue in opposition to Ignatieff (2003) that the process of drafting the UDHR was not a process of western domination, but rather of negotiating and debating opposing and contradictory ideological, religious, political and cultural values systems in relation to human rights. When Eleanor Roosevelt concluded that east and west should agree to disagree on certain philosophical grounds regarding the nature of human beings, Ignatieff (2003) reads this as silencing. Whereas I read it as keeping conflict and tension open in dialogue - not having to reach consensus on every aspect of human rights foundation. 
The UDHR became a document questioning the unequal power relations in the world; a common statement against oppression and marginalization of people, of migrants, of refugees, of noncitizens. The fascinating fact that such a declaration, for the people and against oppression in all forms, was possible when delegates from opposing cultural, ideological, political and ethnic perspectives met to draft the UDHR in 1948 has inspired this paper. Can this temporal consensus on human rights in 1948, as a cosmopolitan space, enlighten the discourse on human rights today and the presumed dichotomy between universality and particularity?

1.Keeping the UDHR open for interpretation in conflicting cultural narratives by excluding references to particular values

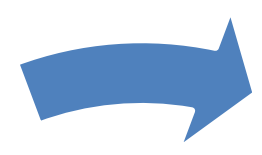

$$
\begin{aligned}
& \text { 2.Reading international } \\
& \text { policy documents on } \\
& \text { human rights into } \\
& \text { cultural narratives }
\end{aligned}
$$

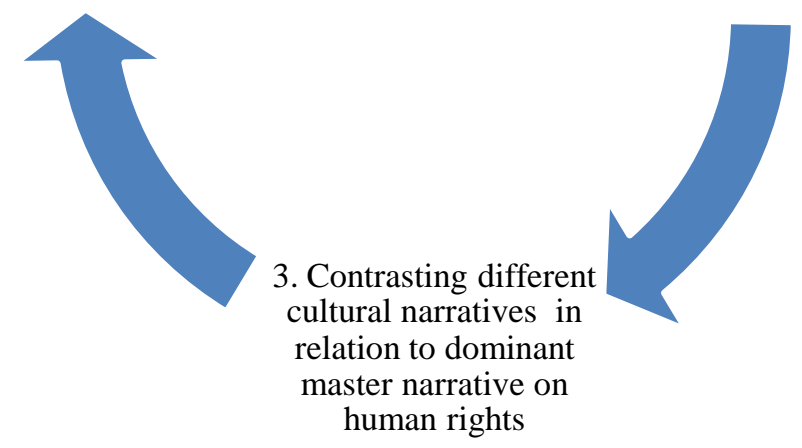

(C)Rebecca Adami

Figure 1: Reconciling Universality and Particularity in Human Rights Discourse

Charles Taylor (1999) said that the concept of human rights 'could travel better if separated from some of its underlying justification'(Taylor 1999, p.126). This paper has examined that empirically; separating the notion of universal human rights from its denotation with western values deriving from liberalism and natural law, by arguing that human rights found their philosophical foundation in different, but antagonistic philosophy and ideology, in the drafting of the UDHR in 1948. Hence, there is a need for further research, both highlighting more in depth the historical contributions of nonwesterners in the drafting of human rights 1948 and reaffirming universality of human rights in 1993 at the Vienna Conference. I agree with Ignatieff (2003) when he concludes that 'a universal regime of human rights protection ought to be compatible with moral pluralism', but I stress with this paper that it already is. 


\section{References}

Andreopoulos, C. 1997, Human Rights Education for the Twenty-First Century, University of Pennsylvania Press, Philadephia.

Benhabib, S. 2008, Another Cosmopolitanism, Oxford University Press, New York.

Borges, M. 2010, 'From national to cosmopolitan: the blueprint of space in citizenship debates', SGIR $7^{\text {th }}$ Pan-European Conference 2010, Stockholm, Sweden, pp.1-24.

Charvet, J. 1998, 'The possibility of a cosmopolitan ethical order based on the idea of universal human rights', Millennium - Journal of International Studies vol. 27 no.3, pp.523-541.

Gibson,G \& Somers, M. 1994, 'Reclaiming the epistemological “other”: narrative and the social constitution of identity', in Social Theory and the Politics of Identity, ed. Calhoun, C. Oxford, Blackwell Press, pp.37-99.

Glendon, M. 2001, A World Made New, Random House, New York.

Griffin, J. 2008, On Human Rights, Rainolds Room, Oxford.

Horsdal, M. 2011, Telling Lives; Exploring Dimensions of Narratives, Routledge, London.

Ignatieff, M. 2003, Human Rights as Politics and Idolatry, Princeton University Press, New Jersey.

Kleingeld, P., \& Brown, E. 2006, Cosmopolitanism. Retrieved October 2011 from http://plato.stanford.edu/entries/cosmopolitanism/

Langlois, A. 2001, The Politics of Justice and Human Rights - South East Asia and Universalist Theory, Cambridge University Press, Cambridge.

Lauren, P. 2003, The Evolution of International Human Rights, Second Edition, University of Pennsylvania Press, Philadelphia.

Li, X. 2006, Ethics, Human Rights and Culture - Universalism and Cultural Relativism in Ethics, Palgrave, Gordonsville.

Morsink, J. 1999, The Universal Declaration of Human Rights -Origins, Drafting and Intent, University of Pennsylvania Press, Philadelphia.

Nussbaum, M. 2003, Cultivating Humanity, a Classical Defense of Reform in Liberal Education, Harvard University Press, Cambridge.

Rizvi, F. 2008, 'Epistemic virtues and cosmopolitan learning', The Australian Educational Researcher, vol. 35, no. 1 pp.17-35.

Taylor, S. 1997, 'Critical Policy Analysis: exploring contexts, texts and consequences', Discourse: Studies in the Cultural Politics of Education, vol.18, no.1, pp.23-35.

Taylor, C. 1999, 'Conditions of an unforced consensus on human rights', in Bauer, J. \& Bell, D. (eds), The East Asian Challenge for Human Rights, p.126

Tesón, F. 1985, 'International Human rights and Cultural Relativism', Virginia Journal of International Law, vol.25, no.4, pp.869-98.

UNESCO, 1947, Comite sur les principles philosophiques des droits de l'homme, part I . UNESCO, 1948, Human Rights, Comments and Interpretations, 25 July . 